\title{
The Implementation of Differentiated Instruction in English Language Learning to Students with Dyslexia in A' Senior Class (A1) in an English Language Center: An Action Research
}

\author{
Xanthoula Nikolaou \\ BA School of English, Aristotle University of Thessaloniki \\ MA in Special Educational Needs, Metropolitan College, Thessaloniki \\ E-mail: xanthoulanikol@gmail.com
}

Dr. Makrina Zafiri

ESP/EAP

ESP/EAP Language Teacher at the Aristotle University of Thessaloniki

Tutor at the Hellenic Open University

External Collaborator with the UEL, Metropolitan College, Thessaloniki

E-mail: m_nzafiri@yahoo.gr

$\&$

Dr. Vassiliki Pliogou

School of Education, Aristotle University of Thessaloniki

Academic Coordinator at the Department of Early Childhood Studies and Special Education, Metropolitan College of Thessaloniki in collaboration with the UEL

President of OMEP in Thessaloniki, Greece

E-mail: pliogouv@gmail.com

Received: July 3, 2017 Accepted: August 1, 2017 Published: August 1, 2017

doi:10.5296/jse.v7i3.11495 URL: https://doi.org/10.5296/jse.v7i3.11495 


\section{Abstract}

The purpose of this study is to investigate the implementation of differentiated instruction as a means of teaching English to children with dyslexia (A' senior level) at a private English Language Center, located in the suburbs of the city of Thessaloniki, in Greece. For the present action research, three ten-year-old male students participated in ten lessons designed according to the principles of differentiated instruction. The lessons took place once a week for one hour and they lasted for two and half months. The methodology used for this small scale search, was qualitative, as semi-structured interviews were applied to both the students and their mothers. According to the findings of this small scale action research study, the method of differentiated teaching is an effective method of teaching a foreign language to students with dyslexia.

Keywords: differentiated instruction, CEFR A1 level, dyslexia, remedial teaching 


\section{Introduction}

\subsection{The Common European Framework of Reference for Languages in A1 \& A2 Level}

The Common European Framework of Reference for Languages (CEFR) is a framework which was published in 2001 and in which students' abilities are described regarding the speaking, reading, listening and writing skills within six different language levels. Apart from these levels, the CEFR provides a number of definitions, scales and examples which can be used by educators who want to communicate their teaching goals. These levels are tools which are used to compare students' skills and to map their progress (North, 2006).

According to the A1 level for the reading skills of students who are learning a foreign language, the CEFR explicitly states that "the students can understand familiar names and very simple words, for example on notices or posters or in catalogues" (Council of Europe, 2006: 4). At the A2 Level, on the other hand, students can read very short and simple texts. More specifically, "they can find specific predictable information in everyday material such as advertisements, prospectuses, menus and timetables. They can understand short simple personal letters" (Council of Europe, 2006: 4).

\subsection{Differentiated Instruction in Foreign Language Teaching and Learning}

Teachers and educators always search for new methods and approaches for their teaching so that students will be able to reach an optimum linguistic level. However, traditional teaching approaches and methods appear to be insufficient for students with learning disabilities, such as dyslexia. As a result, many of these students have negative feelings their learning process. Also, the new approaches to teaching a foreign language facilitate the understanding of the different characteristics of each student which may influence his/her academic progress (Gregory \& Chapman, 2002).

The class environment, on the other hand, is a mosaic that reflects the world around us. The students come to class with different levels of knowledge and skills, with different linguistic and cultural backgrounds, with varied interests and different learning profiles (O'Meara, 2010). Therefore, each student has the need for a teaching process which will provide him/her with more incentives to optimally use their learning skills (writing, listening, speaking, reading) depending on their level of learning (A1, A2) of the foreign language using topics which relate to the students themselves and the world around them (Ministerio de Educación, 2012). Diversity, as well as a wide variety of choices, challenges and opportunities appear to be the basic components which will urge them to implement their skills. These components are the foundation of differentiated instruction (Heacox, 2002).

The teachers, who use differentiated instruction, provide students with options so that they can, in turn, utilize the different levels of readiness, their personal interests and learning profiles. Additionally, when differentiated instruction is implemented, teachers have to adapt their teaching materials so as to offer their students a variety of choices thus allowing them to use the knowledge they have gained during the lesson (Tomlinson, 1995). This means that in differentiated instruction more and more students have access to the learning process in a more effective manner (Tomlinson, 1999). 


\subsection{Dyslexia and Differentiated Instruction}

According to Miles (1995), dyslexia cannot be clearly defined. Different scientific fields, such as medicine, psychology, pedagogy, which are also related to the study of dyslexia, give a different explanation for its causes. Apart from the fact that it is defined as a learning disability, dyslexia has proved to be a set of different but very specific learning difficulties such as attention deficit and hyperactivity (Attention Deficit Hyperactivity Disorder ADHD), dyspraxia, dysgraphia and dysarithmia (Elliot \& Place, 2004 ; Reid, 2009).

The definition of dyslexia given by the British Dyslexia Association (1989) is considered more descriptive and more inclusive. According to this definition, dyslexia is a combination of abilities and difficulties that affect the learning process in one or more skills (reading, spelling, writing) but it also refers to shortcomings in other fields, such as speed of processing, speech and motor skills (Peer \& Reid, 2003 ; Reid, 2009).

Reid's definition (2009) refers to individual differences, the importance of learning styles and the concept of learning. According to the same definition, dyslexia is often characterized by difficulties in reading and writing. It can also affect other cognitive aspects such as memory, speed of processing, management time, and synchronization. In some cases, visual and phonological difficulties are present and there can be a difference in performance in different fields of learning.

Undoubtedly, students with dyslexia have difficulty in reading and writing due to their weakness to acquire the alphabetic knowledge (Snowling, 2000). It has also been proved that the way these difficulties are expressed is affected by the characteristics of the language itself and the teaching method which is being followed (Papadopoulos, 2014). Thus, Greek students with dyslexia, who are taught English as a foreign language, have to practice a new language system which differs from their native language because English is characterized by complexity both at a phonological and at a morphological level (Griva, Semoglou \& Geladari, 2010).

Thus, a multisensory course could include all the components of the foreign language such as, verbal activities (repetition of previous ones), phonological teaching, grammar and syntax teaching, vocabulary teaching orally, reading combined with differentiated instruction methods (Papadopoulou, Papatzikis \& Pliogou, 2015). Additionally, systematic training in a range of strategies will enable students to choose those that they feel comfortable with and employ them for carrying out a task (Rachanioti, Griva \& Alevriadou, 2016).

Difficulties in learning a foreign language are also related to students' oral and writing skills in L1 (Smythe, Salter \& Everatt, 2004). Thus, memorization is very important when learning a foreign language and students with dyslexia need support in memorizing words and phrases as they exhibit deficits in their ability to recognize words (Hanna \& Dettmer, 2004).

The application of differentiated teaching aims to convert traditional learning material into more accessible teaching and learning for all students and especially for the students with dyslexia enabling them to demonstrate what they can achieve through a satisfactory learning process and through assessment (Reid, 2009). Teachers can differentiate and adapt their 
material and also accept students' different responses according to their abilities and skills (Crombie, 2000). According to the Declaration of Salamanca (1994), students with special education needs should have access to regular classes where their needs are recognized and accepted through the use of a student-centered learning process (Johnson, 2004).

The use of adapted material and resources for the students with dyslexia is very important. The availability of the appropriate material is one of the most important assessments in the teaching of students with dyslexia (Mackay, 2004). Apart from the material which has been adapted to meet the needs of students with dyslexia, experts have placed emphasis on the use of ICT (Information and Communication Technology) as a teaching tool (Hunter - Carsch, 2001).

The adaptation of the material which is being used by students with dyslexia is also closely related to the use of semiotics. The implementation of semiotics, which refers to the replacement of a context with pictures and / or sounds, has proven to be an effective teaching and learning tool for students with dyslexia (Matsouki, Zafiri \& Pliogou, 2014).

Teachers reported that they are able to detect dyslexia through the deficits the students present especially in their reading and writing skills despite the fact that they often feel insufficiently trained to provide instruction based on the individual learning profiles of the students (Avloniti, Zafiri \& Pliogou, 2016).

According to Thompson and Chinn (2001), spelling correction in differentiated teaching is a challenge for teachers. They also argue that spelling should be assessed according to its content and the spelling errors that the students with dyslexia produce. According to Nijakowska (2000), the descriptive assessment method appears to be ideal in such cases. Crombie \& McColl (2001) point out that teachers should provide students with dyslexia with extra time so as to be able to complete their task.

As for homework, Mackay (2004) argues that teachers should assign differentiated exercises without reducing the quantity of tasks. But Pollock \& Waller (2003) emphasize upon the need for teachers to be cautious about the amount of homework assigned to them because students with dyslexia tend to become listless, languid and board very easily.

Remedial teaching is supported teaching and is based on the method of differentiated instruction. According to this method, students with dyslexia attend extra classes in small groups or pairs (Pumfrey \& Reason, 1991). As remedial teaching has proved to be effective, the students who participated in the present study have received remedial teaching in an attempt to boost their skills.

The purpose of the present study is to examine the implementation of differentiated instruction as a method of English language teaching for students with dyslexia at an A2 CEFR Level in an English Language Center. 


\section{Methodology}

\subsection{Participants}

In the present study, the sample was selected from an English Language Center in the suburbs of the city of Thessaloniki, in Greece. The sample consisted of three ten-year old male students and their mothers. For the purpose of anonymity only the first letter of the names of the participants was used.

\subsection{Procedure}

For the needs of this research study, a variety of tools were used for data collection. The first tool which was used was the semi-structured interview, which enabled the interviewer to guide the interviewee in an attempt to elicit information from the subject under scrutiny (Robson, 2007).

In the present study, the students, their mothers and the teacher took part in three separate interviews. The students were asked about their attitude towards the school, the difficulties they faced and whether the teaching method(s) applied to them was or were interesting, or not, for them. As for their mothers, they offered demographic data, which included their children's age, educational background, health problems, etc. They were also asked about the difficulties their children faced in L1 and L2 learning and also offered solutions to the problems their children were facing.

The interviews lasted 30 to 40 minutes and took place in a private place which was the students' home so that students would feel more comfortable. The same procedure was followed with the mothers.

The second tool used in the present study is that of educational intervention. This method of academic intervention was used because it is a strategy used to encourage students to apply existing skills in new settings and concepts using different kinds of materials. In particular, educational intervention is a means and a set of actions which can change a specific educational trajectory (Methe \& Riley -Tillman, 2008).

For the present study, the aforementioned method was implemented by the students' regular teacher who was also part of the research team within ten classes of differentiated teaching which were planned according to the principles of differentiated instruction and lasted ten weeks (one teaching hour per week). For the needs of this research, the Elliott action research model (1991) was used, which consists of four different phases (planning-acting-observing-reflection) and aims to improve the students' performance. For this reason, the ten lessons planned were based on the content of the course book which is used in the main syllabus.

Students were given a pre-test to write before they attended their classes with a view to identify weaknesses or deficits in the aforementioned skills. Also, the pre-test enables the researcher to identify the students' knowledge of the foreign language. After completing the classes, the students were given a post-test so as to identify the effectiveness of the implementation of differentiated foreign language teaching. 


\subsection{Description of the book-based lesson plans}

The lesson plans were based on the student's book A' Senior Level "Our World B" content and they were designed according to the method of differentiated instruction aiming to improve the skills which are necessary for A1 level according to the CEFR.

In particular, the first lesson was based on Lesson 14 with the title "London" and the aim was for the students to understand and use the vocabulary related to travelling and sightseeing. As for the procedure, the students watched a video related to London and they completed the first Worksheet with the item they identified in the footage. In the next stage of the lesson, the students watched the video again and they gave answers to the second Worksheet. In the last stage of the lesson, the students were asked to write an email to a friend on their computers on what they know about London.

The next lesson was based on Lesson 16 entitled "The Food Festival". The teaching aim of this lesson was for students to learn to use oral and written vocabulary related to food. In the second phase of the lesson, the teacher presented a video with cartoons to the students and asked them to identify the fruit and vegetables from Worksheet 1 as these fruit and vegetables were displayed in the video. In the next phase, the teacher asked the students if they went to restaurants with their family and asked them to fill out a restaurant list with their own ideas. In the third phase, the teacher asked the students to write an email to a friend from a foreign country to describe Greek food and present it on the worksheet.

The third lesson was based on Lesson 20 of the book "My Favorite Film," and the students were assigned to write and talk about their favorite film. In the first stage, the teacher asked the students "What's your favorite film? What kind of film it is?". Then, she asked them to match the kinds of movies with the pictures in Worksheet 1 . In the second phase of the third lesson, the teacher asked the students to listen to people talking about their favorite movies and to match the two columns from Worksheet 2.

The fourth lesson was based on Lesson 23 with the title "The Trojan Horse" focusing on reading and writing skills. In the first stage of the lesson, the teacher showed a picture to the students and how they should present their peers at a party and then she asks them: "Where are the children? What are they doing? Do you like parties? Have you been to a party recently? What did you do there? ". In the second phase of the lesson, the teacher opens her bag and shows students a birthday invitation. Showing it to the students, she says: "Yesterday I got a call for a party. I will give it to you so that you can all read it together and then you can write your own invitation for a party". In this way, using a hands-on activity, the teacher wanted to strengthen cooperation between students by taking another step towards the implementation of differentiated teaching.

The fifth lesson plan was based on Lesson 24 of the book, "The Lost Envelope". The teacher's teaching goal was for the students to be able to talk and write about their experiences with the use of the present perfect and talk about events from the past with the use of the past simple. In this way the teacher could control the understanding of the previous lesson and also teach the difference between the past simple and the present perfect simple and its different uses when 
talking about experiences. In this lesson, emphasis was placed on the use of songs and videos as suggested by the students and their mothers in their interviews.

The sixth lesson plan was based on Lesson 25 entitled "The Competition" and the teaching goal was for students to use question words. In the initial stage of the lesson, the teacher asked the students "What questions do you ask people when you first meet them?". The students watched a video and completed the gaps using the words given. In the next phase, the teacher handed out Worksheet 2 to all students and asked them to write their plans for the weekend.

The seventh lesson was based on the 26th Lesson of the book "The school trip", the teaching goal is for students to be able to use the Present Continuous. At the beginning of the lesson the teacher asks the students: "What are you doing at the weekend? Are you playing sports? Are you shopping?". In the second phase, the teacher told the students that they would watch a video about the future plans of a basketball player and asked them to choose the right answer for Worksheet 1.

She also asked them to present their plans in the classroom. In the last stage of the lesson, the teacher asked the students to make a poster with each student's schedule for the weekend and also to paint pictures. All three students were enthusiastic and their cooperation was better than the original lessons.

The eighth teaching plan was based on the 29th Lesson of the book "The Surprise", and the teaching goal set was to allow students to set rules by using the verb must / must not. In the first phase of the lesson, the teacher asked the students: "What must students do at school? What students should not do at school?". She gave them Worksheet 1 and asked them to match the rules with the pictures. The students responded to the questions and asked if they would also have to construct a poster during the course of the lesson. They also responded correctly to the worksheet. In the next stage, the teacher gave them a new Worksheet 2 and told them that they would watch a video with students who set up rules for their school and once they had finished watching the video they would answer Worksheet 2 . The three students answered correctly by asking their teacher for words that they did not know. In the next stage, the teacher handed out the new Worksheet 3 and asked them to watch another video and note the correct answer on Worksheet 3. In the final stage of the lesson, the teacher told them that they would now have to choose the five best rules from those which they had learnt in the course of their lessons and to present them, in the form of a poster, to the class.

The ninth lesson plan was based on the 30th Lesson with the title "Katie's Adventure". The teaching objective of the lesson was for the students to be able to talk and write about obligations and rules using must / must not and can / cannot. They also learned to use vocabulary related to outdoor activities. The final teaching plan was based on the 31 st Lesson of the book which taught students to speak and write about differences using the comparative degree of the adjectives. In the first stage of the lesson, the teacher showed some cards to the students asking them: "Is this man stronger than the other man? Is the turtle faster than the tiger?". The students watched a video and completed the correct word in the worksheet. In the last stage, the teacher told them that they would play a board game. They had to form a sentence using the comparative and superlative degree so as to acquire points. 
After completing the lessons, the next step was to sit for the post-test.

\section{Results}

\subsection{Results of the pre-test}

The pre-test consisted of multiple -choice questions and short answers and it was divided into two separate sections which dealt with writing and reading skills. According to the results, the three students appear to have vocabulary learning difficulties and they seemed unable to use the foreign language appropriately in the sense that they were unable to read and write, the same occurred with the students who were not diagnosed with dyslexia.

\subsection{Results from the interviews}

\subsubsection{Results from the students' interviews}

The questions of the semi-structured interviews for the students were divided into three main areas. The first area concerned personal information, as well as the interests of the students. The second area dealt with the students' attitude to the school environment and their strengths and weaknesses. The third and last area dealt with the matter which concerned their dyslexia problems and the differentiated lessons which they attended and which were conducted in the English Language Center.

As for the first part of the questionnaire, X. answered that he preferred playing computer games alone. He appeared to have a positive attitude to the school environment but he pointed out that he had some difficulties without giving further clarifications as to which these difficulties were. He appears to be interested in math and has an aversion to the Greek language. He cheerfully mentioned that he is generally good in mathematics and physical education ("...I feel really confident with math and P.E...I am really into them...). The second student, B, said that he preferred to play football and computer games. He has a positive attitude to the school environment but he does not like examinations and tests (...I am fond of school...I've got friends there but I can't stand tests...). He likes history but he finds it difficult to understand some words (...Some words appear to be completely unknown ...I' $m$ bored when I have to look them up in a dictionary...). The last student, G, expressed his preference for leisure time activities such as computer games and watching TV. He takes part in team sports but he was hesitant to express his view about school (...Hmmm...School is good...but...I don't know.... I find myself in a difficult position...). As for dyslexia, he mentioned that he understood that he was different compared to his classmates but he pointed out that he could do things that other students were unable to do (...Oh yes !!! I know a few things about dyslexia.... Mum has told me that it makes me special...with special skills...I mean that I do some things that my classmates cannot do...”). He had a positive attitude towards the support he received from his teacher before and after the class. 


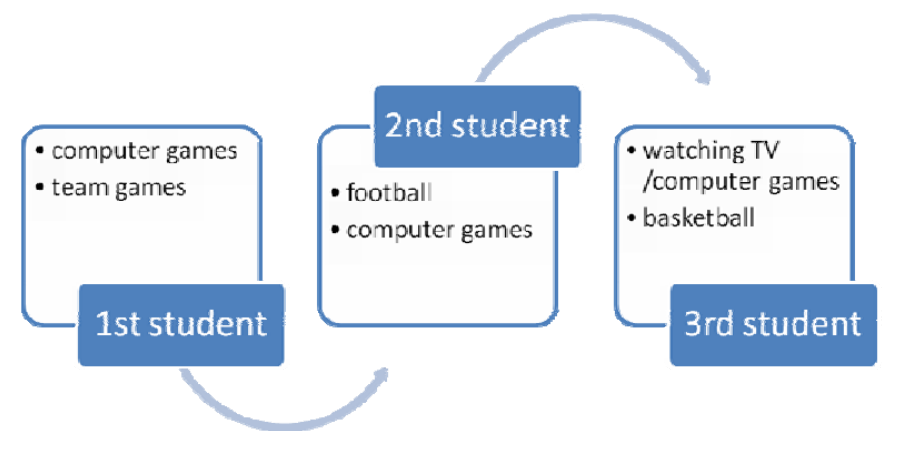

\subsubsection{The results from the mothers' interviews}

The questions for the semi-structured interviews which were directed to the mothers were divided into three main parts. The first part dealt with their personal information and history, the second part included questions which concerned the child's dyslexia and his learning difficulties and the final part related to questions which concerned the support that the student received.

$\mathrm{X}$ 's mother is 35 and she is a university graduate but she has never worked as she chose to devote her life to her family. She gave birth to $X$ at the age of 25 and she did not have any problems during her pregnancy. She had a caesarean delivery and X had no health problems during infancy. As a toddler, $\mathrm{X}$ was hyperactive. As a result, he had accidents which were not of a serious nature. As for the student's cognitive skills, the mother replied that he spent hours doing things he liked, for example playing with his favorite toy, without responding to his relatives' calls. (...He spent hours playing without responding.... It was something that made me anxious...). Regarding his difficulties with L1, the mother replied that he had problems with the use of tenses. The mother also pointed out that it took her son a long time to overcome it. The mother also added that one of his weaknesses is writing and spelling (...Writing and spelling had always been great obstacles...but now things are better...). He is better at oral tasks but he is hesitant to communicate orally in the foreign language for fear of making a mistake. Dyslexia was detected by his teacher in the first class of elementary school, who advised the mother to consult the official State Center. The mother admitted that she was upset when dyslexia was diagnosed because she thought it would define her child's academic future (...Initially, I thought that it would be an obstacle for his academic success...). As for English language learning, $\mathrm{X}$ has problems with spelling, writing and reading but he is interested in the lesson and also participates. The mother appeared to be satisfied with the support provided by the English Language Center and she pointed out that specific activities, such as making posters, songs and videos are the most interesting part of the lesson for her son.

Regarding the second mother, she is at the age of 39 and she is a High School graduate. During her pregnancy, she had high levels of anxiety due to the prenatal examinations which she was expected to take. She had a caesarean delivery. B was a low weight baby without any other health problems. The main weaknesses of B were his spelling and writing difficulties 
and he also had difficulty with the use of the appropriate article. Another one of his weaknesses is that he is unable to memorize words with an abstract meaning (...he has great difficulty in memorizing the meaning and the spelling of words...). Dyslexia was detected by his teacher in the second class of Elementary School, who advised the mother to consult the official State Center. When she was informed about the student's dyslexia, she become upset due to the influence it might have on his mood and school performance. Despite the fact that his participation in class is not satisfactory, his attitude towards the English language and the English language classes which he is attending, is positive. Finally, the mother appears to be satisfied with the support provided by the English Language Center (...I'm really satisfied with the support I received by the staff of the English Language Center...).

G's mother is 39 and she works as a Math teacher at a state High School. She gave birth to G. at the age of 28 and she had a normal delivery. Apart from an infection at the age of 2, G has not experienced any other serious health problems. G's main weakness is writing. In English, he finds it difficult to remember words. Dyslexia was detected by his teacher in the second class of Elementary School, who advised the mother to consult the official state center. G's mother remains calm about his dyslexia because she has encountered such problems at work (...my profession helped to see the symptoms and helped me to stay calm...). The mother appears to be satisfied with the support provided by the English Language Center as the teacher gives valuable advice to the parents but she added that a different teaching method should be adopted.

\subsubsection{The results from the action research}

According to the journal in which their students' progress was reported, the results of the action research were both encouraging and motivating. The three students showed a positive attitude towards the new method of teaching. The application of multimedia, as a tool for teaching English as a foreign language, and the colorful pictures, also used by the teacher, attracted the three students and thus, their attention was not distracted. The video facilitated them in finding new ideas for their writing tasks (Picture $1 \& 2$ ) and they were also urged to talk about their personal experiences thus practicing their oral skills. Hands-on activities (Picture $3 \& 4$ ) improved their cooperation and their behavior. Their personal experiences were the spark that kept their interest intact.

Despite the fact that the lesson time was never sufficient, the students improved their grammar and vocabulary and they were able to write more extensive texts. They also improved their oral skills and pronunciation. Their reading skills also improved in spite of the fact that they grew weary at times.

As concerning the contents of the activities which were applied in differentiated teaching, they were based on the contents of the coursebook of A' Senior Level "Our World B" and they were designed to boost the students' skills which are necessary at an A1 level according to the CEFR. After the completion of the pre-test, the students' weaknesses became clear and it was also clear that these weaknesses had to do, mainly, with their writing and speaking skills and more particularly with their vocabulary and their spelling. Ten class lessons based on differentiated instruction were conducted after the completion of the pre-test. 


\section{Macrothink}

The students had a positive attitude towards the new method. The use of multimedia and pictures attracted their attention. The videos contributed to vocabulary acquisition and it (the video) was used for writing and speaking as well. The implementation of hands-on activities improved both collaboration among the students and their willingness to talk about personal experiences. The students made some grammar and spelling mistakes. Most of the students did not ask for extra time to complete the tasks despite the fact that they were tired with the listening activities. Overall, their oral and writing skills were improved and extra time was not necessary for them. As for their behavior in class, the students became more cooperative and interested in the lesson's contents.

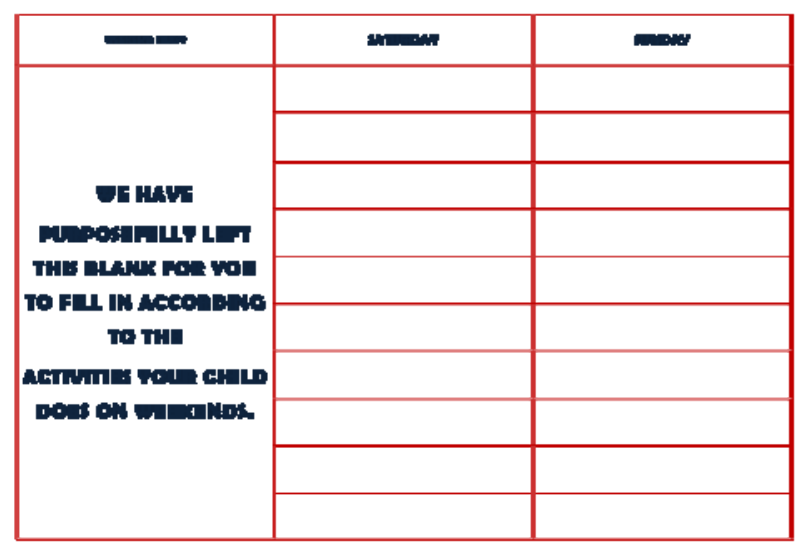

Picture 1. Exercise 1 from the video

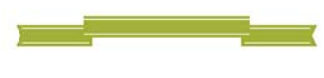

[Menu Title]

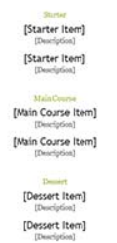

Picture 2. Exercise 2 from video

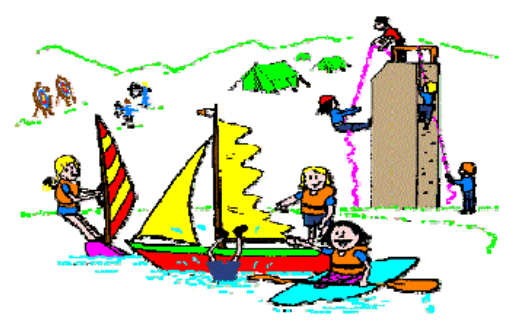

Picture 3 . Hands - on activity 


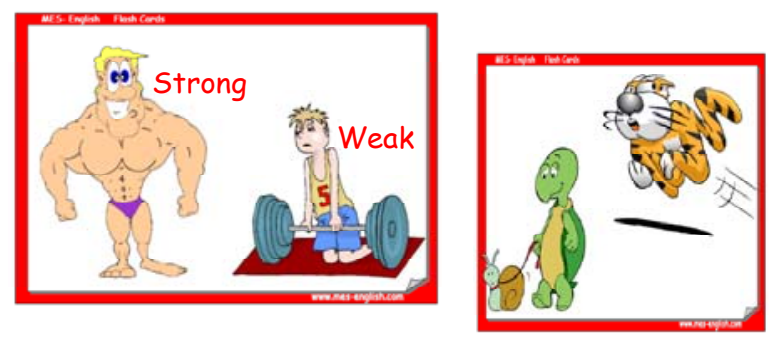

Picture 4. Hands - on activity

\subsubsection{Results from the post-test}

The results from the post-test were as expected. Compared with the pre-test, the majority of the answers were correct and the students were less stressed. They wrote a longer more coherent text. Two students did not require extra time to complete the test, something which occurred when they wrote the post-test.

\section{Discussion}

The findings indicated that differentiated instruction improved students' school performance and their behavior in the school classroom. More particularly, they improved their reading and writing skills as well as their interpersonal skills.

Summarizing the mothers' answers, the majority of the findings are consistent. As for their children, none of them had any serious health problems during their infancy and early childhood. Also, the students did not appear to have problems in their social adjustment and inclusion at school despite the fact that they prefer to take part in individual activities.

Additionally, the students appear to have less severe problems in their oral language compared to their written language in which they exhibited problems in spelling and word memorization. Dyslexia was noticed by the students' teachers in Elementary School. It is worth mentioning that dyslexia was diagnosed by the experts of the Special State Centers (KEDDY), in Greece which means that the mothers followed the teachers' advice for expert consultancy, regardless of their educational background. All mothers appear to be stressed with dyslexia, focusing mainly on its impact on their child's psychological condition and the amount of support their children would receive from their teachers. The teacher answered that, informing parents, about their child's dyslexia, is always a very stressful situation.

All mothers are content with the support their child received from the English Language School despite the fact their child needed support at home with his studies. Also, all students were satisfied with their classes in the English Language School they attended, although sometimes they were reluctant to respond to the teachers' questions. The mothers agree that a different method of teaching would help more students with dyslexia regarding their academic performance and independence in learning the foreign language.

The action research and the results of the post-test showed improvement in the students' reading and writing skills and their behavior towards the English language also improved (Tomlinson, 1999). 
There is also a strong correlation between the use of multimedia and the students' achievement (Hunter - Carsch, 2001). The students' interests and attitudes towards the learning process appeared to be excellent because the lessons were adapted according to their personal experiences and preferences (Ministerio de Educación, 2012). The wide variety of choices in topics and tasks contributed to their participation in the foreign language (Tomlinson, 1995).

The findings also indicated that remedial teaching helped students with dyslexia to participate in the main syllabus thus covering knowledge gaps (Mackay, 2004). As a result, they participated more in activities with the rest of the class. Furthermore, the feedback, regarding spelling corrections, which the teacher provided to the students, as well as the extra time which she offered to them, appeared to be very effective (Nijakowska, 2000 ; Crombie \& McColl, 2001).

Generally speaking, remedial teaching based on differentiated instruction proved to be effective for the aforementioned students with dyslexia and constituted a valuable teaching tool. Finally, after remedial teaching and according to the CEFR (Council of Europe, 2006), the three students' level of knowledge is A1 as they can successfully complete the tasks which are described by the CEFR.

\section{Concluding Remarks}

The aforementioned research proves that differentiated instruction, for students with dyslexia at level A1, contributed effectively to their academic as well as their foreign language improvement. Systematic training in their reading and writing skills, based on differentiated instruction, enabled students to effectively apply their abilities and skills. Remedial teaching was suggested as well.

The limited number of students who participated in this small scale research, the absence of female subjects and their different levels of language learning knowledge are some of the limitations of the present study. Thus, the results cannot be considered conclusive.

Further research on a larger sample is suggested in order to investigate the efficiency of differentiated instruction in Greek schools, so that we can come to safer conclusions.

\section{References}

Avloniti, O., Zafiri, M., \& Pliogou, V. (2016). Early detection of dyslexia in the First Grade of Primary School. Multilingual Academic Journal of Education and Social Sciences, 4(2), $15-28$.

Council of Europe. (2006). European Language Portfolio (ELP): Key Reference Documents. Strasbourg: Council of Europe (DGIV/EDU/LANG, 2006, 4).

Crombie, M. (2000). Dyslexia and the Learning of a Foreign Language in School: Where Are We Going? Dyslexia, 6, 112-123. https://doi.org/10.1002/(SICI)1099-0909(200004/06)6:2<112::AID-DYS151>3.0.CO;2-D 
Crombie, M. \& McColl, H. (2001). Dyslexia and the teaching of modern foreign languages. In L. Peer \& G. Reid (Eds.). Dyslexia: Successful Inclusion in the Secondary School. London: David Fulton.

Elliot, J. (1991). Action Research for Educational Change. Milton Keynes: Open University Press.

Gregory, G., \& Chapman, C. (2002). Differentiated instructional strategies: One size does not fit all. Thousand Oaks, CA: Corwin Press, Inc.

Griva, E., Semoglou, K., \& Geladari, A. (2010). Early Foreign Language Learning: implementation of a Project in a game-based context. Selected Volume: Procedia Social and Behavioral Sciences, ELSEVIER, 2, 3700-3705. https://doi.org/10.1016/j.sbspro.2010.03.575

Hanna, G. S., \& Dettmer, P. A. (2004). Assessment for effective teaching: Using contextadaptive planning. Boston, MA: Pearson A\&B.

Heacox, D. (2002). Differentiating Instruction in the Regular Classroom: How to Reach and Teach all Learners, grades 3-12. Minneapolis, MN: Free Spirit Publishing Co.

Hunter-Carsch, M. (2001). Learning support in the Secondary School: needs analysis and provision for dyslexic students. In M. Hunter-Carsch \& M. Herrington (Eds.), Dyslexia and Effective Learning in Secondary and Tertiary Education. London: Whurr Publishers.

Johnson, M. (2004). Dyslexia-friendly schools-policy and practice. In G. Reid and A. Fawcett (Eds.), Dyslexia in Context: Research, Policy and Practice. London: Whurr. https://doi.org/10.1002/9780470777916.ch14

Mackay, N. (2004). The case for dyslexia-friendly schools. In G. Reid. \& A. Fawcett (Eds.), Dyslexia in Context: Research, Policy and Practice. London: Whurr. https://doi.org/10.1002/9780470777916.ch13

Matsouki, S., Zafeiri, M., \& Pliogou, V. (2016). The teaching of English to third grade students with dyslexia through the use of Semiotics. The stance taken by teachers. In K. D. Malafantis, V. Papadopoulou, S. Avgitidou, G. Iordanidis, I. Mpetsas (eds.). Proceedings of the 9th Panhellenic Conference of the Hellenic Educational Society entitled "Hellenic Pedagogy and Educational Research", School of Education of the University of West Macedonia (pp. 1765-1781). Athens: Diadrasi. [in Greek].

Methe, S. A., \& Riley-Tillman, T. C. (2008). An informed approach to selecting and designing early mathematics interventions. School Psychology Forum: Research into Practice, 2, 29-41.

Miles, E. (1995). Can there be a Single Definition of Dyslexia? Dyslexia, 1(1), 37-45.

Ministerio de Educación. (2012). The English Language Learning Standards. Quito: MinEduc.). https://doi.org/10.15446/profile.v19n1.55676

North, B., Ortega, A., \& Sheehan, S. (2010). A Core Inventory for General English. British Council/EAQUALS. 
O’Meara, J. (2010). Beyond Differentiated Instruction. Thousand Oaks, CA: Corwin.

Papadopoulos, I. (2014). Creative writing activities and TPR plus: An implementation of foreign language development project to students with dyslexia Multilingual Academic $\begin{array}{llll}\text { Journal of Education and Social Sciences, } & \text { 67-95. }\end{array}$ https://doi.org/10.6007/MAJESS/v2-i1/1019

Papadopoulou, D., Papatzikis, E., \& Pliogou, V. (2015). Researching dyslexia through the learning of a foreign language: a case study. "Polydromo" Periodical for Bilingualism and Multiculturalism in Education and Society, 8, 7-16. Retrieved from: http://www.polydromo.gr/pdf/issues/8\%CE\%BF\%CE\%A4\%CE\%B5\%CF\%8D $\%$ CF\%87\%C $\mathrm{E} \% \mathrm{BF} \% \mathrm{CF} \% 82 . p d f$ (Last access on 07/30/2017). [in Greek]

Peer, L., \& Reid., G. (2003). Introduction to Dyslexia. London: David Fulton Publishers

Pollock, J., \& Waller, E. (2003). Day-to-Day Dyslexia in the Classroom. London: Routledge.

Pumfrey, P. D. \& Reason, R. (1991). Specific Learning Difficulties (dyslexia) Challenges and Responses. New York: Routledge

Rachanioti, L, Griva, E. \& Alevriadou, A. (2016). Children 'Think Aloud' and 'Talk About' Vocabulary Strategies in an Integrated Memory-based Text Framework. Journal of Studies in Education, 7(1), 61-88. https://doi.org/10.5296/jse.v7i1.10425

Reid, G. (2009). Dyslexia: A Practitioner's Handbook (4rd ed.). West Sussex: John Wiley \& Sons Ltd. https://doi.org/10.1002/9780470745502

Smythe, I., Salter, R. \& Everatt, J. (Eds.) (2004). The International Book of Dyslexia: A Guide to Practice and Resources. New York: Wiley.

Snowling, M. J. (2000). Dyslexia (2 ${ }^{\text {nd }}$ ed). UK: Wiley Blackwell Publication.

The Declaration of Salamanca Statement (1994). World Conference on Special Needs Education: Access and Quality. United Nations \& Ministry of Education of Spain. Retrieved from http://www.ecdgroup.com/download/gn1ssfai.pdf. (Last access on 07/30/2017).

Tomlinson, C. (1995). Differentiating Instruction for Advanced Learners in the Mixed-ability Middle School Classroom. Reston, VA.: ERIC Clearinghouse on Handicapped and Gifted Children.

Tomlinson, C. (1999). The Differentiated Classroom: Responding to the Needs of all Learners. Alexandria, VA: Association for Supervision and Curriculum Development. 